\title{
Peran Administrasi Pertanahan dalam Pengendalian Pemanfaatan Kawasan Pertanian Lahan Basah Kabupaten Bogor
}

\author{
The Role of Land Administration in Controlling the Utilization of Wetland Agricultural \\ Areas in Bogor Regency
}

\author{
Pramusintha Nugraha $^{1 *}$, Budi Mulyanto ${ }^{2} \&$ Khursatul Munibah ${ }^{2}$
}

\begin{abstract}
${ }^{1}$ Program Studi Ilmu Perencanaan Wilayah, Fakultas Pertanian, Institut Pertanian Bogor, Jalan Meranti, Kampus IPB Dramaga, Bogor, Jawa Barat, 16680, Indonesia; ${ }^{2}$ Departemen Ilmu Tanah dan Sumberdaya Lahan, Fakultas Pertanian, Institut Pertanian Bogor, Jalan Meranti, Kampus IPB Dramaga Bogor, Jawa Barat, 16680, Indonesia; *Penulis korespondensi.e-mail: pramnug86@gmail.com

(Diterima: 3 November 2011; Disetujui: 25 Januari 2021)
\end{abstract}

\begin{abstract}
The area of irrigated rice fields during 2017-2018 has decreased by 19.84\% in Indonesia and $30.10 \%$ in Bogor Regency. Wetland agricultural area of Bogor Regency Spatial Plan (RTRW) is intended for wetland food crops (lowland rice) which are cultivated intensively because their potential to provide an irrigation system thus urge to be protected. In certain conditions, land registration has impact on the conversion of agricultural land. This study aims to examine the relationship between land administration and the conversion of agricultural land. Interpretation of Google Earth imagery and field checks are methods for inventories of constructed land. The relationship between the variable $y$ (built-up area) and the variable $x$ (land administration) is modeled by Geographically Weighted Regression (GWR). Literature study of land administration regulations was carried out to understand the modeling results with the realities that occur in the field. The dynamics of land administration are greatest in the northern part of Central WP Bogor Regency, in the suburbs of South Tangerang City, and Depok City. The modeling produces a global value of $R^{2} 0.72$ and local $R^{2} 0.44$ to 0.86 , meaning that land administration has the opportunity to become an instrument of control, by tightening the service requirements specified in the Regulation of the Head of the National Land Agency RI No. 1 Tahun 2010.
\end{abstract}

Keywords: control of spatial use, Geographically Weighted Regression, land administration, land use change

\begin{abstract}
ABSTRAK
Luas sawah irigasi di Indonesia tahun 2017-2018 mengalami pengurangan sebesar 19.84\% dan Kabupaten Bogor 30.10\%. Kawasan pertanian lahan basah RTRW Kabupaten Bogor diperuntukan tanaman pangan seperti padi pada lahan basah (sawah) yang dapat diolah secara intensif karena didukung tersedianya sistem irigrasi sehingga perlu dilindungi. Kondisi tertentu, pendaftaran tanah membawa dampak ikutan berupa alih fungsi lahan pertanian. Penelitian ini bertujuan melihat hubungan kegiatan administrasi pertanahan terhadap alih fungsi lahan pertanian. Metode interpretasi citra Google Earth dan cek lapang untuk inventarisasi lahan terbangun. Hubungan variabel y (lahan tebangun) dengan variabel x (administrasi pertanahan) dimodelkan dengan Geographically Weighted Regression. Studi literatur peraturan dan perundangan administrasi pertanahan dilakukan guna memahami hasil pemodelan tersebut dengan kenyataan yang terjadi di lapangan. Dinamika administrasi pertanahan terbesar di bagian utara WP Tengah
\end{abstract}


Kabupaten Bogor, pada suburban Kota Tangerang Selatan dan Kota Depok. Pemodelan menghasilkan nilai global $\mathrm{R}^{2} 0.72$ dan local $\mathrm{R}^{2} 0.44 \mathrm{~s} / \mathrm{d} 0.86$, artinya administrasi pertanahan berpeluang menjadi instrumen pengendalian yaitu dengan memperketat syarat-syarat permohonan pelayanan yang telah ditetapkan pada PerKaBan RI No. 1 Tahun 2010.

Kata kunci: administrasi pertanahan, alih fungsi lahan, GWR, pengendalian alih fungsi lahan pertanian

\section{PENDAHULUAN}

Kabupaten Bogor merupakan bagian dari Kawasan Perkotaan Jakarta-Bogor-DepokTangerang-Puncak-Cianjur (JabodetabekPunjur). Kawasan Bogor-Puncak-Cianjur (Bopunjur) merupakan daerah hulu yang diarahkan menjadi Kawasan Konservasi. Kawasan Konservasi pada Kabupaten Bogor lebih cenderung berfungsi sebagai kawasan resapan air, perlindungan lahan yang memiliki kemiringan di atas 40\%, kawasan suaka alam, dan taman wisata alam. Hingga saat ini, tiga fungsi strategis Kabupaten Bogor sebagai penyangga bagi Provinsi DKI Jakarta, yaitu (1) sebagai pengembangan pemukiman perkotaan bagian dari sistem Metropolitan Jabodetabek; (2) kawasan konservasi karena letak geografisnya di bagian hulu dalam sistem tata air di Metropolitan Jabodetabek; serta (3) kawasan pengembangan pertanian (Pemda Kabupaten Bogor, 2016). Keberhasilan pembangunan di Kabupaten Bogor menjadi salah satu parameter keberhasilan di Kawasan Perkotaan Jabodetabek-Punjur yang merupakan miniatur sistem negara dan cerminan pembangunan di Indonesia (Djakapermana, 2009), terutama dalam era pengendalian pemanfaatan ruang.

Berdasarkan data Statistik Lahan Pertanian Tahun 2014-2018 terbitan Kementerian Pertanian (2019), menunjukkan perubahan luas lahan pertanian di Indonesia yang salah satunya diakibatkan alih fungsi lahan pertanian. Luas sawah irigasi di Indonesia pada tahun 2017-2018 mengalami pengurangan sebesar $19.84 \%$ dan lebih besar daripada pengurangan luas sawah non irigasi yang berada pada angka $3.43 \%$. Kondisi berkurangnya luas lahan sawah irigasi yang lebih besar daripada pengurangan luas sawah non irigasi juga terjadi pada Kabupaten Bogor. Luas lahan sawah irigasi Kabupaten Bogor tahun 2017-2018 berkurang dengan angka $30.10 \%$. Ketidakselarasan kawasan lahan pertanian basah di Kabupaten Bogor, diduga pada tahun 2025 akan mengalami konversi menjadi lahan terbangun sebesar 13.4 ha atau 4.5\% dari total luas Kabupaten Bogor (Fajarini et al., 2015). Penyebab laju konversi lahan sawah yang tinggi pada suatu daerah adalah tingginya tingkat kepadatan penduduk (Dwinanto et al., 2016). Tingginya tingkat kepadatan penduduk, juga cenderung diikuti aktivitas yang lebih kompleks, menjadikan tingginya tingkat kebutuhan lahan perumahan, pembangunan infrastruktur, industri, dan jasa (Munawir et al., 2019).

Berdasarkan Peraturan Daerah Kabupaten Bogor Nomor 11 Tahun 2016 tentang RTRW Kabupaten Bogor 2016-2036, alokasi Kawasan Pertanian Lahan Basah diperuntukkan tanaman pangan padi sawah. Kawasan Pertanian Lahan Basah mempunyai potensi sistem irigasi dari pemanfaatan air permukaan, maka lahan tersebut dapat diolah secara intensif dan perlu dilestarikan sumber airnya. Dokumen RTRW Kabupaten Bogor 2016-2036 menetapkan bahwa Kawasan Pertanian Lahan Basah dialokasikan sebagai Lahan Pertanian Pangan Berkelanjutan (LP2B) dan Kawasan Pertanaian Lahan Kering diarahkan sebagai cadangan LP2B.

Wilayah Pengembangan (WP) Tengah Kabupaten Bogor dipilih sebagai lokasi penelitian karena fenomena konversi Kawasan Pertanian Lahan Basah lebih cenderung terjadi daripada di WP Barat dan WP Timur Kabupaten Bogor. WP Tengah mempunyai jumlah penduduk yang lebih padat dengan 53 jiwa/ha sedangkan WP Barat 25 jiwa/ha dan WP Timur 17 jiwa/ha. WP Tengah mempunyai 
Pusat Kegiatan Wilayah promosi (PKWp) Perkotaan Cibinong yang merupakan kawasan perkotaan yang memiliki potensi bidang tertentu serta kemampuan pelayanan skala setingkat provinsi atau beberapa kabupaten/kota. Wilayah ini juga dianggap strategis karena ditunjang dengan adanya sarana transportasi ke Pusat Ibukota seperti Kereta Rel Listrik (KRL) dan rencana Lintas Rel Terpadu (LRT) yang hanya melintasi WP Tengah. Selain itu, disisi sebelah selatan WP Tengah merupakan bagian dari Kawasan Strategis Provinsi Bogor-Puncak Cianjur sebagai kawasan strategis untuk kepentingan lingkungan hidup dan obyek wisata puncak yang memiliki daya tarik masyarakat dalam melakukan berbagai aktivitas kegiatan.

Sitorus et al. (2002) mengatakan bahwa ada dua jenis relasi manusia (masyarakat, pemerintah, swasta) terkait dengan sumbersumber agraria, yakni "relasi teknis agraria" dan "relasi sosio agraria".

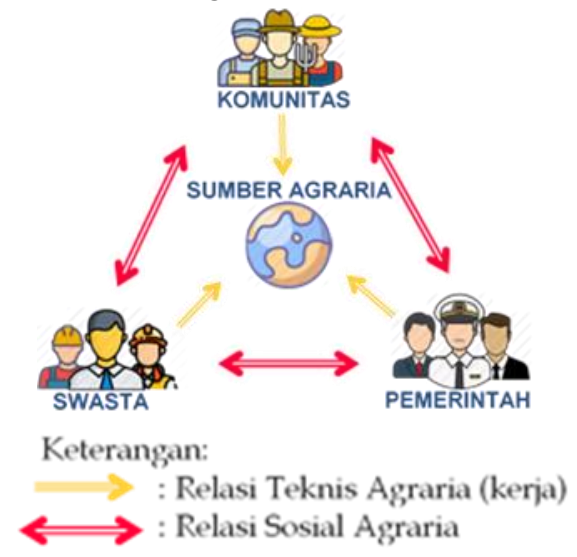

Gambar 1. Lingkup Hubungan Agraria

Relasi yang pertama berkaitan aktivitas kerja (produksi) oleh manusia pada sumbersumber agraria. Sedangkan relasi kedua berkaitan hubungan antar sesama manusia (perorangan, kelembagaan) dalam aktivitas kerja yang dilakukan pada sumber-sumber agraria. Relasi teknis dan sosial agraria di antara ketiga subjek agraria (masyarakat, pemerintah, swasta) ini secara skematis dapat diilustrasikan dalam Gambar 1. Skema lingkup hubungan agraria tersebut dapat diartikan bahwa aktivitas masyarakat menggunakan lahan (relasi teknis agraria), saling berpengaruh dan mempengaruhi aktivitas masyarakat pada urusan administrasi pertanahan (relasi sosio agraria). Administrasi Pertanahan merupakan suatu kegiatan dari organisasi tertentu yakni Badan Pertanahan Nasional dan pengaturan berkaitan dengan terselenggaranya kebijaksanaan pemerintah di bidang pertanahan (Silviana \& Ardani, 2018). Administrasi pertanahan juga diartikan sebagai bagian dari Administrasi Negara yang memiliki tujuan memberikan pelayanan di bidang pertanahan kepada masyarakat.

Dampak positif administrasi pertanahan terlihat dari rasio tanah terdaftar terhadap jumlah bidang tanah yang tinggi yang seiring dengan perkembangan wilayah serta pertumbuhan ekonomi (Marzuki, 2018), hal itu karena hak kepemilikan (property right) yang lebih aman berkorelasi positif dengan tingkat investasi dan pertumbuhan ekonomi suatu negara. Sertifikasi tanah dapat meningkatkan keamanan tenurial, investasi terkait tanah dan partisipasi di pasar tanah (Deininger et al., 2011). Pendaftaran tanah melalui sertifikasi tanah secara potensial meningkatkan nilai tanah (land value), kondisi sosial ekonomi dan kesejahteraan masyarakat pemegang hak atas tanah (Mardiana et al., 2016) serta dapat mengurangi konflik batas tanah (Holden et al., 2010). Peraturan Presiden Nomor 86 Tahun 2018 tentang Reforma Agraria bahwa tanah bersertipikat memberikan kesempatan akses permodalan maupun bantuan lain bagi pemegang sertipikat hak atas tanah.

Namun dalam keadaan tertentu, administrasi pertanahan juga dapat berdampak negatif. Motif masyarakat melakukan kegiatan administrasi pertanahan dalam rangka usaha penggunaan dan pemanfaatan tanah yang sering diikuti konversi lahan. Dinamika spasial tanah terdaftar diikuti pula dengan dinamika transaksi tanah, nilai tanah, dan perlu mewaspadai adanya fenomena konversi lahan (Amir et al., 2020). Sertifikasi tanah dalam kondisi tertentu membawa dampak ikutan, yaitu semakin mudahnya peralihan hak atas tanah melalui jual beli tanah (Syahyuti, 2016). Alih fungsi lahan sawah dapat terjadi secara tidak langsung yaitu 
diawali oleh alih penguasaan atau pemilikan terlebih dahulu (peralihan hak atas tanah) (Sumaryanto et al., 2005). Marak adanya penjualan tanah kavling dengan sistem kredit melalui bank (hak tanggungan), menjadikan kemudahan alih penguasaan kepemilikan lahan tersebut. Banyak kasus tanah kavling tidak digunakan dan dimanfaatkan sesuai dengan peruntukannya, padahal sebelumnya merupakan lahan pertanian yang produktif (Sumarto et al., 2010). Menurut Winoto (2005) bahwa faktorfaktor pendorong konversi lahan pertanian salah satunya faktor sosial budaya. Keberadaan hukum waris yang menyebabkan terfragmentasinya tanah pertanian (pemisahan atau pemecahan sertipikat tanah), sehingga tanah hasil pemisahan/pemecahan tidak mencukupi batas minimum skala ekonomi usaha tani yang menguntungkan. Alih fungsi lahan juga disebabkan adanya pemahaman sertipikat hak atas tanah merupakan hak ekslusif, sehingga pemegang hak merasa bebas menggunakan dan memanfaatkan tanah tanpa melihat arahan rencana tata ruang.

Penelitian ini bertujuan melihat hubungan motif masyarakat melakukan administrasi pertanahan dengan alih fungsi lahan di Kawasan Pertanian Lahan Basah WP Tengah RTRW Kabupaten Bogor serta peran administrasi pertanahan dalam pengendalian alih fungsi lahan.

\section{METODOLOGI}

Penelitian ini dilakukan pada Kawasan Pertanian Lahan Basah di WP Tengah RTRW Kabupaten Bogor [Gambar 2], yang meliputi 54 (lima puluh empat) desa. Secara geografis Kabupaten Bogor terletak pada $6^{\circ} 21^{\prime 2} 27^{\prime \prime}$ 6 48'21" Lintang Selatan dan 106 37'11" 106 57'53" Bujur Timur.

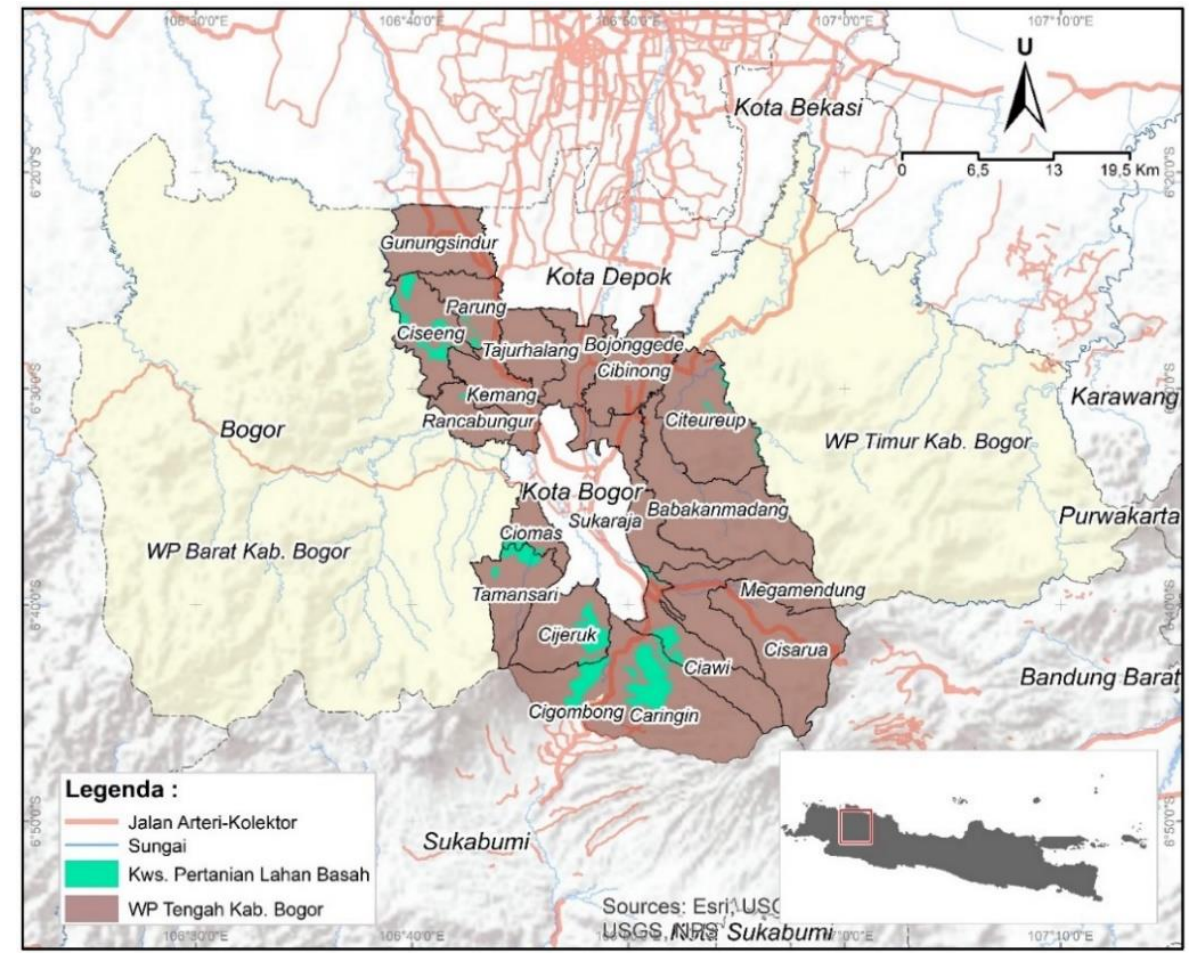

Gambar 2. Peta lokasi penelitian

Jenis dan sumber data sekunder yang dipakai dalam penelitian ini yaitu: dokumen RTRW Kabupaten Bogor 2016-2036 yang bersumber dari Dirjen Tata Ruang Kementerian ATR/BPN; batas administrasi pemerintahan desa, persil bidang tanah tahun 1961-2019, riwayat administrasi pertanahan tahun 19612019, citra satelit Google Earth bulan Mei 2019 dari Kantor Pertanahan Kabupaten Bogor, Peraturan Kepala Badan Pertanahan RI Nomor 1 tahun 2010 tentang Standar Pelayanan dan Pengaturan Pertanahan. 
Pengumpulan data primer yang dilakukan dalam penelitian ini meliputi pengecekan lapang terhadap peta tentatif penggunaan lahan aktual. Cek lapang untuk memastikan lahan terbangun merupakan bangunan permanen dan bukan bangunan pendukung sektor pertanian lahan basah. Peta tentatif tersebut dibuat melalui overlay persil bidang tanah diatas citra satelit Google Earth, kemudian dilakukan interpretasi citra guna mengidentifikasi lahan terbangun pada Kawasan Pertanian Lahan Basah. Lahan terbangun pada citra satelit Google Earth sangat mudah dikenali dan dibedakan dengan lahan pertanian [Gambar 3]. Interpretasi citra menggunakan unsur rona dan warna dalam identifikasi lahan terbangun.

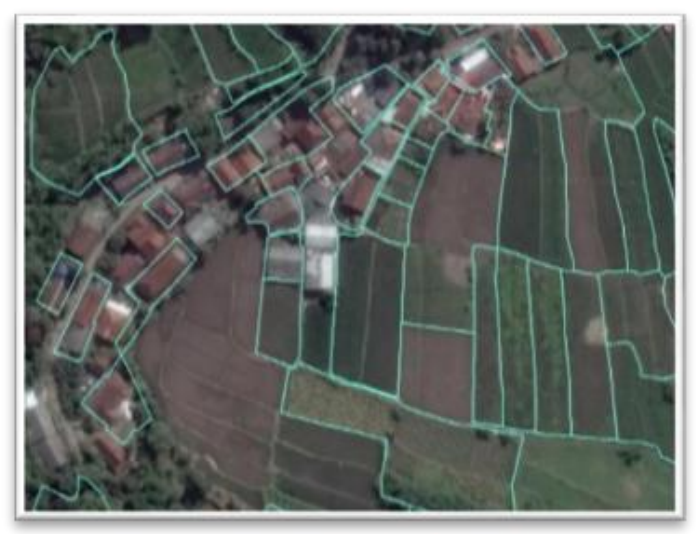

Gambar 3. Keadaan penggunaan tanah

Titik sampel cek lapang ditentukan dengan purposive sampling, yaitu satu sampel di setiap polygon Kawasan Pertanian Lahan Basah pada persil bidang tanah penggunaan lahan terbangun dengan mempertimbangkan aksesibilitas. Jumlah titik sampel dengan perhitungan rumus Slovin, sehingga ditentukan sebanyak 97 titik sampel dari 3,082 persil bidang tanah terbangun

Jenis kegiatan administrasi pertanahan yang diinventaris dan dispasialkan meliputi pendaftaran tanah pertama kali, pemisahan/pemecahan bidang tanah, peralihan hak, dan hak tanggungan. Jenis kegiatan administrasi pertanahan yang dipilih tersebut ditentukan karena memiliki dampak ikutan berupa alih fungsi lahan pertanian atau menyertai terjadinya konversi lahan pertanian.
Analisis pengaruh kegiatan administrasi pertanahan terhadap keberadaan lahan terbangun menggunakan Geographically Weighted Regression (GWR). GWR dapat digunakan sebagai alat penelitian variasi spasial berupa visualisasi dan satu set regresi yang bersifat lokal disebabkan hubungan antara variabel dependen dengan independen (Pravitasari et al., 2015). Model GWR dapat ditulis sebagai berikut:

$$
y_{i}=\beta_{0}\left(u_{i}, v_{i}\right)+\sum_{k=1}^{p} \beta_{k}\left(u_{i}, v_{i}\right) x_{i k}+\varepsilon_{i},
$$

di mana:

$y_{i}=$ nilai observasi variabel dependen ke- $i$;

$x_{i k}=$ nilai observasi variabel independen ke- $k$ di lokasi pengamatan ke- $i$;

$\beta_{0}\left(u_{i}, v_{i}\right)=$ konstansta/intercept pada pengamatan ke- $i$;

$\left(u_{i}, v_{i}\right)=$ menyatakan titik koordinat letak geografis lokasi pengamatan ke- $i$;

$\beta_{k}\left(u_{i}, v_{i}\right)=$ koefisien regresi variable independen ke- $k$ dilokasi pengamtan ke- $i$;

$\varepsilon_{i}=$ error pengamatan ke- $i$ diasumsikan identik, independen dan berdistribusi normal dengan mean nol dan varian konstanta $\sigma^{2}$

$$
i=1,2, \ldots, n
$$

Variabel dependen (y) menggunakan data jumlah persil bidang tanah penggunaan lahan terbangun dan variabel independen (x) menggunakan data pendaftaran tanah pertama kali, pemisahan/pemecahan bidang tanah, peralihan hak, hak tanggungan.

Studi literatur peraturan dan perundangan administrasi pertanahan dilakukan guna memahami hasil pemodelan tersebut dengan kenyataan yang terjadi di lapangan terkait pengendalian alih fungsi lahan. Identifikasi unsur-unsur pengendalian alih fungsi lahan dalam peraturan dan perundangan administrasi pertanahan menggunakan matriks inventarisasi. Jenis administrasi pertanahan yang diidentifikasi mengandung unsur pengendalian alih fungsi lahan harusnya memiliki koefisien regresi variabel independen yang cenderung kecil. 


\section{HASIL DAN PEMBAHASAN}

\section{Penggunaan Lahan Terbangun}

Kondisi penggunaan lahan terbangun hasil cek lapangan pada Kawasan Pertanian Lahan Basah WP Tengah Kabupaten Bogor antara lain dapat terlihat pada Gambar 4. Hasil pengecekan lapang terhadap peta tentatif penggunaan lahan terbuangun menyimpulkan bahwa persil bidang tanah lahan terbangun hasil interpretasi citra sesuai dengan kenyataan di lapangan. Beberapa bangunan diantaranya merupakan rumah tempat tinggal dengan kondisi bangunan masih baru yang terlihat dari desain bangunan dan bahkan juga ditemui rumah tinggal yang sedang dilakukan proses pembangunan. Hal tersebut dapat diartikan bahwa proses alih fungsi lahan pertanian pada Kawasan Pertanian Lahan Basah masih kerap terjadi.

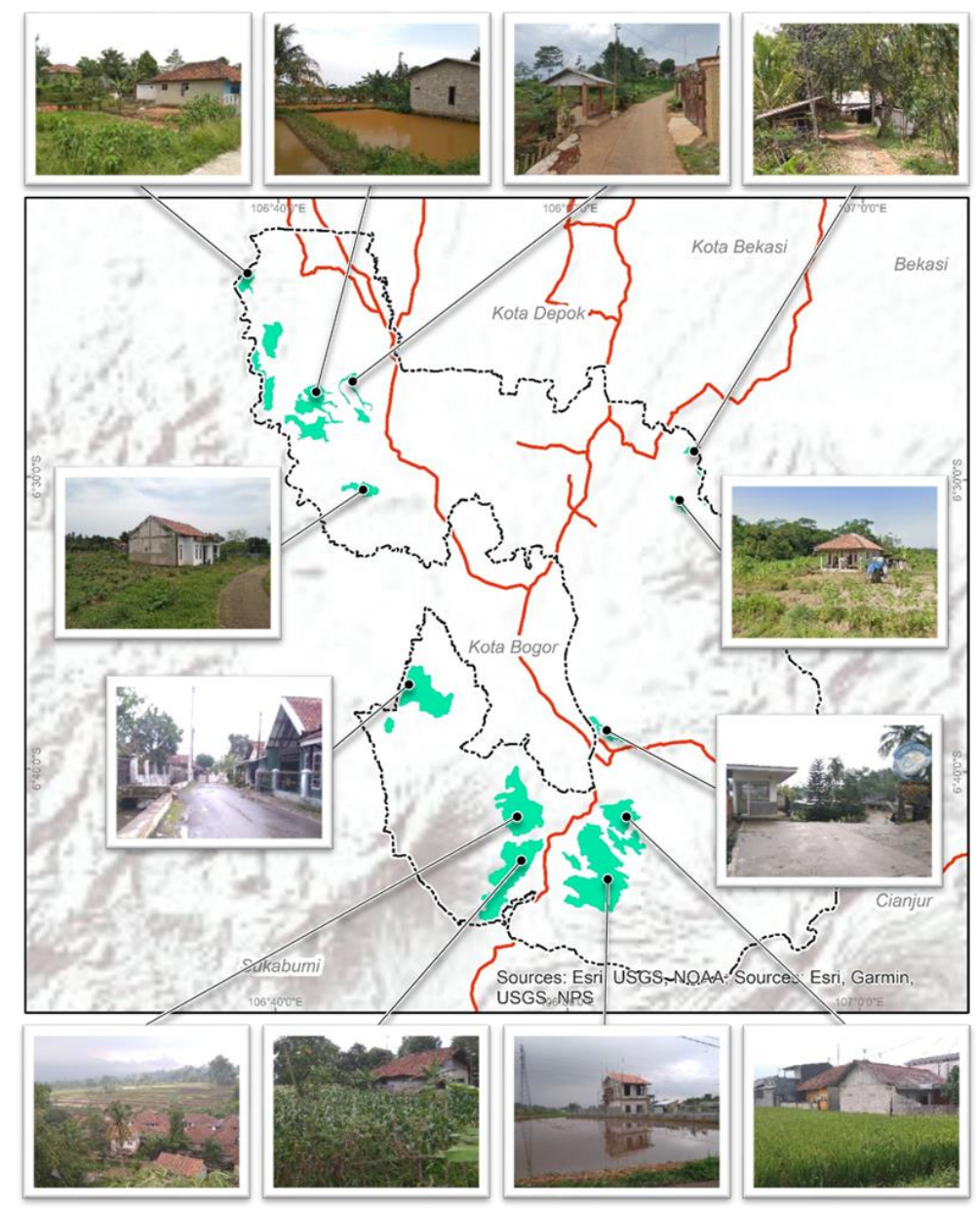

Gambar 4. Hasil pengecekan lapang penggunaan dan pemanfaatan lahan terbangun

Terdapat beberapa persil bidang tanah yang sebagian masuk Kawasan Pertanian Lahan Basah. Hal tersebut dapat dipahami bahwa Kawasan Pertanian Lahan Basah pada RTRW Kabupaten Bogor dengan ketelitian skala 1 : 100,000 sedangkan persil bidang tanah dapat disajikan dengan skala 1 : 1,000. Selain itu, penetapan alokasi pola ruang RTRW belum menggunakan dasar batas persil bidang tanah. Prabowo (2019) menyimpulkan bahwa perlu penyesuaian peta-peta RDTR dan RTRW agar sesuai dengan batas peta bidang tanah, sehingga arahan penggunaan/pemanfaatan tanah lebih akurat dan pasti.

Angka rasio persil lahan terbangun menggambarkan banyaknya persil lahan terbangun per total persil bidang tanah pada Kawasan Pertanian Lahan Basah WP Tengah yang terdata di Kantor Pertanahan Kabupaten Bogor. Total persil bidang tanah pada data Aplikasi KKP (Komputerisasi Kegiatan Pertanahan) unit kerja Kantor Pertanahan 
Kabupaten Bogor terdiri dari beberapa status persil bidang tanah, yaitu tervalidasi, terdaftar, terukur, dan terdelineasi. Rasio persil lahan terbangun menandakan besarnya konversi lahan yang terjadi. Tingkat rasio lahan terbangun pada Kawasan Pertanian Lahan Basah tiap desa di WP Tengah Kabupaten Bogor dapat diamati pada Tabel 1 dan Gambar 5.

Tabel 1. Rasio persil lahan terbangun

\begin{tabular}{ll}
\hline Rasio & Desa \\
\hline $0.668-1$ & Warujaya, Caringin \\
$0.334-0.667$ & Banjarwangi, Cibalung, Putatnutug, Pasireurih, Sukaluyu, Ciadeg, Citapen, Banjarsari, \\
& Cinagara, Cipelang, Cimande, Cisalada, Sukajaya, Pasirjaya, Warungmenteng, Sukaresmi, \\
& Cipicung \\
& Cibedug, Gunungsindur, Pasirangin, Tangkil, Lemahduhur, Karihkil, Ciseeng, Kuripan, \\
& Palasari, Ciburayut, Pancawati, Jampang, Tugujaya, Parakan, Pandansari, Telukpinang, \\
& Sukaraharja, Bojongsempur, Ciderum, Tajur, Iwul, Pabuaran, Pasirmuncang, \\
& Cibeuteungmuara, Babakan, Cibanon, Pasirmukti, Candali, Cileungsi, Parigimekar, \\
& Sukamakmur, Cibeuteungudik, Gunungsari, Pasirbuncir, Tegal \\
\hline
\end{tabular}

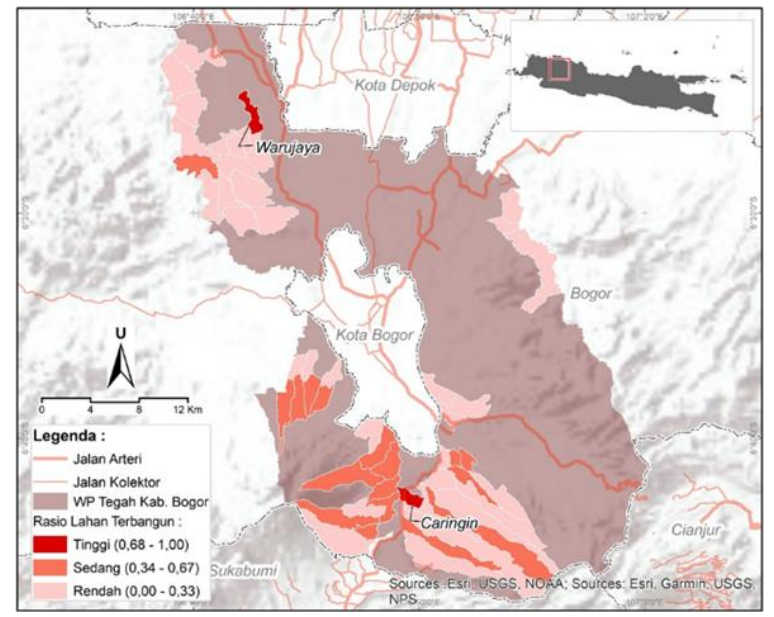

Gambar 5. Persebaran rasio lahan terbangun

Kelas rasio tinggi $(0.68 \mathrm{~s} / \mathrm{d}$ 1) berada pada Desa Warujaya dan Desa Caringin. Desadesa dengan kelas rasio tinggi cenderung berada dekat Pusat Kegiatan Lokal promosi (PKLp) yang merupakan kawasan perkotaan yang memiliki potensi di bidang tertentu sehinga dapat melayani skala tingkat Daerah dan merupakan embrio kawasan perkotaan (Perda Kab. Bogor No. 11, 2016). Overlay Gambar 5 dan Gambar 6, maka Desa Warujaya dekat dengan PKLp Parung dan Desa Caringin dekat dengan PKLp Caringin. Penggunaan lahan sawah dekat perkotaan yang memiliki fasilitas sosial dan umum lengkap, maka kecenderungan berpeluang terjadi konversi yang lebih besar (Munawir et al., 2019).

Desa dengan kelas rasio sedang $(0.34 \mathrm{~s} / \mathrm{d}$ 0.67), mayoritas tersebar di bagian selatan WP

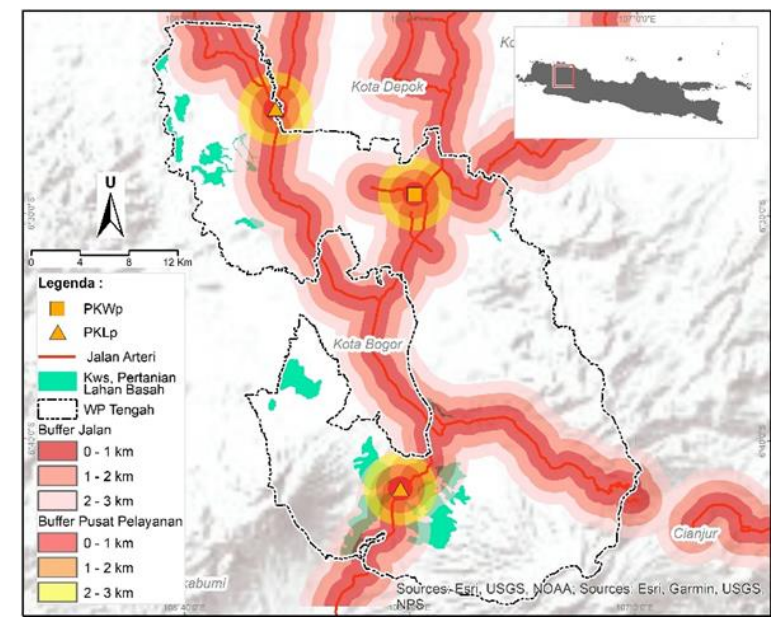

Gambar 6. Struktur Ruang

Tengah Kabupaten Bogor. Persebaran Kawasan Pertanian Lahan Basah bagian selatan WP Tengah Kabupaten Bogor [Gambar 6] cenderung lebih dekat dengan jalan arteri dibandingkan dengan Kawasan Pertanian Lahan Basah di lokasi lain. Jaringan jalan juga merupakan salah satu faktor penting dalam mendorong konversi lahan atau dengan kata lain bahwa rata-rata luas perubahan lahan sawah ke penggunaan lahan non sawah menjadi semakin kecil ketika jarak sawah dari jalan semakin jauh (Barus et al., 2012).

\section{Riwayat Administrasi Pertanahan}

Persebaran jumlah persil bidang tanah di tiap desa Kawasan Pertanian Lahan Basah pada WP Tengah Kabupaten Bogor dapat diamati pada Tabel 2 dan Gambar 7. Semakin besar 
jumlah riwayat administrasi pertanahan di desa tersebut maka semakin besar diameter lingkaran diagram dan juga menunjukkan besarnya dinamika administrasi pertanahan. Urutan ranking lima (5) terbesar yaitu Desa Cibeuteung Muara, Desa Cibeuteung Udik, Desa Ciseeng, Desa Babakan, dan Desa Kuripan. Desa-desa tersebut cenderung tersebar di bagian utara WP Tengah Kabupaten Bogor atau dapat dikatakan dekat dengan wilayah Kota Tangerang Selatan dan Kota Depok.

Komposisi jenis kegiatan administrasi pertanahan pada desa-desa di bagian utara WP Tengah Kabupaten Bogor tersebut mempunyai pola yang berbeda dengan bagian selatan WP Tengah Kabupaten Bogor. Luas juring diagram lingkaran yang berbeda-beda mempresentasikan jumlah yang beragam tiap jenis kegiatan administrasi pertanahan. Kegiatan administrasi pertanahan berupa sertifikasi hak atas tanah lebih sering terjadi dibandingkan kegiatan administrasi pertanahan lain, dan disusul kejadian peralihan hak atas tanah.

Secara global dapat diamati bahwa dinamika administrasi pertanahan terbesar terjadi pada desa-desa WP Tengah bagian utara atau desa-desa wilayah suburban dari Kota Tangerang Selatan dan Kota Depok. Wilayah suburban yang lebih berciri perkotaan mempunyai dinamika administrasi pertanahan yang lebih tinggi bila dibandingkan dengan daerah perdesaan. Dinamika spasial tanah terdaftar diikuti pula dengan dinamika transaksi tanah, nilai tanah, dan perlu mewaspadai adanya fenomena konversi lahan (Amir et al., 2020).

Tabel 2. Jumlah persil beserta dinamika kegiatan administrasi pertanahan

\begin{tabular}{|c|c|c|c|c|c|}
\hline \multirow[b]{2}{*}{ Desa } & \multirow[b]{2}{*}{$\begin{array}{l}\text { Jumlah Persil } \\
\text { Bidang Tanah }\end{array}$} & \multicolumn{2}{|c|}{ Pendaftaran } & \multirow[b]{2}{*}{$\begin{array}{l}\text { Peralihan } \\
\text { Hak }\end{array}$} & \multirow[b]{2}{*}{ Hak Tanggungan } \\
\hline & & $\begin{array}{l}\text { Tanah } \\
\text { Pertama } \\
\text { Kali }\end{array}$ & Pisah, Pecah & & \\
\hline Cibeuteung Muara & 2,608 & 604 & 23 & 226 & 15 \\
\hline Cibeuteung Udik & 1,278 & 141 & 0 & 84 & 5 \\
\hline Ciseeng & 1,272 & 294 & 3 & 183 & 18 \\
\hline Babakan & 1,061 & 814 & 0 & 461 & 15 \\
\hline Kuripan & 993 & 491 & 52 & 144 & 53 \\
\hline Warung Menteng & 973 & 538 & 11 & 69 & 19 \\
\hline Sukamakmur & 762 & 749 & 695 & 23 & 8 \\
\hline Sukajaya & 595 & 562 & 180 & 150 & 225 \\
\hline Cibalung & 372 & 266 & 5 & 62 & 41 \\
\hline Cileungsi & 299 & 269 & 0 & 7 & 5 \\
\hline Tangkil & 287 & 236 & 11 & 91 & 31 \\
\hline Parigimekar & 284 & 88 & 0 & 10 & 0 \\
\hline Ciadeg & 233 & 159 & 19 & 46 & 21 \\
\hline Banjarwangi & 230 & 172 & 0 & 0 & 0 \\
\hline Pandansari & 214 & 165 & 6 & 35 & 15 \\
\hline Tugujaya & 204 & 185 & 2 & 52 & 20 \\
\hline Cimande & 200 & 125 & 9 & 62 & 40 \\
\hline Cipicung & 181 & 155 & 11 & 44 & 12 \\
\hline Parakan & 176 & 172 & 42 & 76 & 67 \\
\hline Pancawati & 175 & 156 & 6 & 53 & 21 \\
\hline Cisalada & 168 & 125 & 6 & 22 & 9 \\
\hline Cipelang & 137 & 101 & 0 & 4 & 9 \\
\hline Candali & 131 & 76 & 0 & 12 & 15 \\
\hline Putatnutug & 124 & 83 & 42 & 2 & 11 \\
\hline Sukaraharja & 104 & 65 & 9 & 0 & 0 \\
\hline Ciburayut & 103 & 71 & 3 & 49 & 18 \\
\hline Citapen & 85 & 80 & 7 & 43 & 15 \\
\hline Cinagara & 84 & 78 & 0 & 33 & 25 \\
\hline Ciderum & 84 & 65 & 2 & 35 & 5 \\
\hline Pasirjaya & 80 & 70 & 1 & 34 & 9 \\
\hline
\end{tabular}


Tabel 2. Lanjutan

\begin{tabular}{llllll}
\hline Desa & $\begin{array}{l}\text { Jumlah Persil } \\
\text { Bidang Tanah }\end{array}$ & $\begin{array}{l}\text { Pendaftaran } \\
\text { Tanah } \\
\text { Pertama } \\
\text { Kali }\end{array}$ & Pisah, Pecah & $\begin{array}{l}\text { Peralihan } \\
\text { Hak }\end{array}$ & Hak Tanggungan \\
\hline Lemahduhur & 80 & 64 & 4 & 39 & 11 \\
Pasirmuncang & 77 & 64 & 0 & 0 & 1 \\
Sukaluyu & 72 & 62 & 41 & 21 & 2 \\
Palasari & 64 & 60 & 3 & 15 & 5 \\
Jampang & 63 & 45 & 1 & 39 & 5 \\
Cibanon & 61 & 19 & 0 & 9 & 0 \\
Telukpinang & 59 & 37 & 0 & 2 & 2 \\
Banjarsari & 53 & 32 & 0 & 2 & 6 \\
Pabuaran & 49 & 46 & 0 & 5 & 0 \\
Karihkil & 45 & 1 & 0 & 28 & 0 \\
Tajur & 41 & 39 & 0 & 19 & 2 \\
Pasireurih & 21 & 0 & 0 & 0 & 0 \\
Sukaresmi & 18 & 12 & 6 & 5 & 8 \\
Pasirangin & 16 & 16 & 1 & 3 & 1 \\
Gunungsari & 16 & 13 & 10 & 0 & 4 \\
Pasirmukti & 14 & 11 & 0 & 3 & 0 \\
Warujaya & 10 & 10 & 0 & 0 & 0 \\
Cibedug & 9 & 9 & 0 & 6 & 0 \\
Iwul & 8 & 8 & 0 & 7 & 0 \\
Caringin & 6 & 5 & 5 & 0 & 0 \\
Gunungsindur & 6 & 5 & 0 & 1 & 0 \\
Bojongsempur & 6 & 6 & 0 & 0 & 0 \\
Pasirbuncir & 2 & 2 & 0 & 0 & 0 \\
Tegal & 0 & 0 & 0 & 0 & 0 \\
\hline Segal KKP & 0 & 0 & 0 & &
\end{tabular}

Sumber: KKP Kantor Pertanahan Kabupaten Bogor, 2019

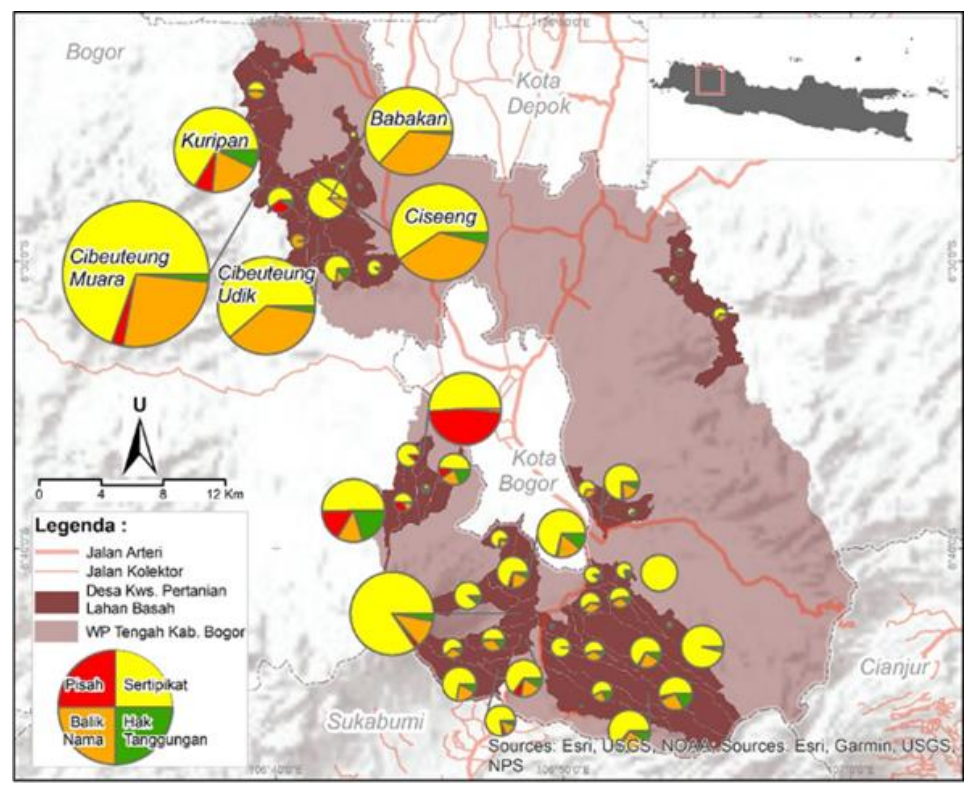

Gambar 7. Persebaran kegiatan administrasi pertanahan

Hubungan Kegiatan Administrasi

Pertanahan terhadap Alih Fungsi Lahan

Uji multikolinearitas bertujuan mengetahui adanya interkorelasi atau kolinearitas antar variabel bebas dalam sebuah model regresi. Interkorelasi merupakan hubungan kuat atau hubungan linear dalam sebuah model regresi (GWR) yaitu antara satu variabel bebas (independent) dengan variabel bebas (independent) lainnya. Interkorelasi yang terjadi dapat diketahui dengan melihat nilai koefisien korelasi antara variabel bebas 
(independent), nilai Variance Inflation Factor (VIF) dan Tolerance, nilai Eigen (Eigenvalue) dan Condition Index, nilai standar error koefisien beta atau koefisien regresi parsial.

Uji multikolinearitas dilakukan dengan software SPSS dengan hasil dan interpretasi sebagai berikut:

1. Tabel Korelasi (Correlations) menunjukkan hasil analisis interkorelasi antara variabel bebas (independent), yang ditandai dengan nilai koefisien korelasi Pearson [Tabel 3].
Persilangan antar variabel bebas yaitu antara variabel pendaftaran tanah pertama kali, variabel pemisahan, variabel peralihan dan variabel hak tanggungan. Hasil persilangan antar variabel bebas tersebut mempunyai nilai $r=0.036-0.761$. Nilai-nilai $r$ tersebut kurang dari 0.8 yang menandakan tidak ada gejala multikolinearitas.

Tabel 3. Tabel korelasi

\begin{tabular}{llllllc}
\hline & $\begin{array}{l}\text { Lahan } \\
\text { Terbangun }\end{array}$ & $\begin{array}{l}\text { Pendaftaran } \\
\text { Pertama }\end{array}$ & Pemisahan & $\begin{array}{l}\text { Peralihan } \\
\text { Hak }\end{array}$ & $\begin{array}{l}\text { Hak } \\
\text { Tanggungan }\end{array}$ \\
\hline Pearson Correlation & Lahan Terbangun & 1.000 & 0.739 & 0.401 & 0.615 & 0.381 \\
& Pendaftaran Pertama & 0.739 & 1.000 & 0.531 & 0.761 & 0.440 \\
& Pemisahan & 0.401 & 0.531 & 1.000 & 0.036 & 0.223 \\
& Peralihan & 0.615 & 0.761 & 0.036 & 1.000 & 0.342 \\
Sig.(1-tailed) & Hak Tanggungan & 0.381 & 0.440 & 0.223 & 0.342 & 1.000 \\
& Lahan Terbangun & - & 0.000 & 0.001 & 0.000 & 0.002 \\
& Pendaftaran Pertama & 0.000 & - & 0.000 & 0.000 & 0.000 \\
N & Pemisahan & 0.001 & 0.000 & - & 0.399 & 0.053 \\
& Peralihan & 0.000 & 0.000 & 0.399 & - & 0.006 \\
& Hak Tanggungan & 0.002 & 0.000 & 0.053 & 0.006 & - \\
& Lahan Terbangun & 54 & 54 & 54 & 54 & 54 \\
& Pendaftaran Pertama & 54 & 54 & 54 & 54 & 54 \\
& Pemisahan & 54 & 54 & 54 & 54 & 54 \\
& Peralihan & 54 & 54 & 54 & 54 & 54 \\
& Hak Tanggungan & 54 & 54 & 54 & 54 & 54 \\
\hline
\end{tabular}

Sumber: Hasil Olah Data SPSS, 2020

\section{Tabel Koefisien $\quad\left(\right.$ Coefficients $^{a}$ )} menunjukkan hasil nilai standar error kurang dari 1 (satu) yaitu antara 0.108 0.285 , serta nilai koefisien beta $(B)$ kurang dari 1 (satu) yaitu antara $0.127-0.289$ [Tabel 4]. Sehingga dari nilai koefisien- koefisen tersebut dapat dikatakan bahwa multikolinearitas tidak terdeteksi;

3. Tabel Koefisien (Coefficients ${ }^{a}$ ) juga menunjukkan hasil nilai VIF dan Tolerance yang merupakan indikasi kuat untuk menyimpulkan fenomena terjadinya interkorelasi variabel bebas [Tabel 4].

Tabel 4. Koefisien ${ }^{\mathrm{a}}$

\begin{tabular}{|c|c|c|c|c|c|c|c|c|c|c|c|c|}
\hline \multirow[b]{2}{*}{ Model } & \multicolumn{3}{|c|}{$\begin{array}{c}\text { Unstandardized Standardized } \\
\text { Coefficients Coefficients } \\
\end{array}$} & \multirow[t]{2}{*}{$d$} & \multirow[b]{2}{*}{ Sig. } & \multicolumn{2}{|c|}{$\begin{array}{l}95.0 \% \text { Confidence } \\
\text { Interval for } B\end{array}$} & \multicolumn{3}{|c|}{ Correlations } & \multicolumn{2}{|c|}{$\begin{array}{c}\text { Collinearity } \\
\text { Statistics }\end{array}$} \\
\hline & B & $\begin{array}{c}\text { Std. } \\
\text { Error }\end{array}$ & Beta & & & $\begin{array}{l}\text { Lower } \\
\text { Bound }\end{array}$ & $\begin{array}{l}\text { Upper } \\
\text { Bound }\end{array}$ & $\begin{array}{l}\text { Zero- } \\
\text { order }\end{array}$ & Partial & $l$ Part & Tolerance & VIF \\
\hline 1 (constant) & 9.781 & 10.559 & & 0.92 & 0.359 & -11.438 & 31.001 & & & & & \\
\hline Pendaftaran Pertama & 0.205 & 0.108 & 0.446 & 1.89 & 0.064 & -0.012 & 0.422 & 0.739 & 0.261 & 0.179 & 0.161 & 6.229 \\
\hline Pemisahan & 0.127 & 0.136 & 0.140 & 0.93 & 0.355 & -0.146 & 0.400 & 0.401 & 0.132 & 0.088 & 0.396 & 2.523 \\
\hline Peralihan & 0.289 & 0.229 & 0.247 & 1.26 & 0.213 & -0.171 & 0.749 & 0.615 & 0.177 & 0.119 & 0.232 & 4.309 \\
\hline Hak Tanggungan & 0.189 & 0.285 & 0.069 & 0.66 & 0.512 & -0.385 & 0.762 & 0.381 & 0.094 & 0.062 & 0.806 & 1.240 \\
\hline
\end{tabular}

a. Dependent Variable : Lahan Terbangun

Sumber: Hasil olah data SPSS, 2020

Jika nilai VIF kurang dari 10 dan atau nilai Tolerance lebih dari 0.01 maka dapat disimpulkan dengan tegas bahwa tidak terdapat masalah multikolinearitas. Hasil 
yang didapat bahwa nilai VIF antara 1.240

- 6.229 dan nilai Tolerance $0.161-0.806$.

\section{Tabel Collinearrity Diagnostic ${ }^{a}$}

menunjukkan nilai Eigenvalue $=0.061$ dan

Condition Index $=6.895$ [Tabel 5]. Jika
Eigenvalue lebih dari 0.01 dan atau nilai kurang dari 30 pada Condition Index, maka dapat disimpulkan bahwa tidak terjadinya gejala multikolinearitas di dalam model regresi.

Tabel 5. Diagnosis Korelasi ${ }^{\mathrm{a}}$

\begin{tabular}{|c|c|c|c|c|c|c|c|c|}
\hline \multirow[b]{2}{*}{ Model } & \multirow[b]{2}{*}{ Dimension } & \multirow[b]{2}{*}{ Eigenvalue } & \multirow[b]{2}{*}{$\begin{array}{l}\text { Condition } \\
\text { Index } \\
\end{array}$} & \multicolumn{5}{|c|}{ Variance Propotions } \\
\hline & & & & (Constant) & $\begin{array}{l}\text { Pendaftaran } \\
\text { Pertama }\end{array}$ & Pemisahan & Peralihan & $\begin{array}{l}\text { Hak } \\
\text { n Tanggungan }\end{array}$ \\
\hline \multirow[t]{5}{*}{1} & 1 & 2.920 & 1.000 & 0.04 & 0.01 & 0.01 & 0.01 & 0.04 \\
\hline & 2 & 0.899 & 1.803 & 0.04 & 0.00 & 0.33 & 0.33 & 0.00 \\
\hline & 3 & 0.582 & 2.240 & 0.23 & 0.00 & 0.01 & 0.00 & 0.84 \\
\hline & 4 & 0.538 & 2.329 & 0.60 & 0.02 & 0.00 & 0.10 & 0.10 \\
\hline & 5 & 0.061 & 6.895 & 0.10 & 0.97 & 0.65 & 0.86 & 0.02 \\
\hline
\end{tabular}

a. Dependent Variable : Lahan Terbangun

Sumber: Hasil olah data SPSS, 2020

Kesimpulan dari poin-poin interpretasi hasil uji multikolinearitas SPSS diatas adalah tidak terdapat masalah multikolinearitas atau dapat dikatakan bahwa hasil pengujian yang reliabel atau terpercaya. Nilai koefisien regresi parsial dapat disebut handal dan kebal jika di dalam model regresi berganda terjadi perubahan-perubahan pada variabel lainnya. Apabila varibel-variabel tersebut dipakai dalam model regresi maka didapat sebuah model regresi yang BLUE (Best Linear Unbiased Estimation) karena semua asumsi terpenuhi dalam regresi.

Hasil analisis GWR diharapkan dapat menjelaskan hubungan motif masyarakat melakukan kegiatan administrasi pertanahan dengan keberadaan lahan terbangun pada Kawasan Pertanian Lahan Basah. Penggunaan dan pemanfaatan tanah (relasi teknis agraria) pada umumnya diikuti atau mengikut kegiatan administrasi pertanahan (relasi sosio agraria), sehingga administrasi pertanahan berpeluang besar menjadi instrumen pengendalian alih fungsi lahan pertanian bila nilai $\mathrm{R}^{2}$ mendekati 1 (satu). Nilai $\mathrm{R}^{2}$ yang mendekati angka 1 (satu) menjelaskan adanya hubungan yang kuat antara variabel dependen dan variabel independen. Tabel 6 menunjukkan bahwa nilai global $\mathrm{R}^{2}$ hasil analisis GWR adalah 0.72 .
Tabel 6. Parameter GWR

\begin{tabular}{lr}
\hline Parameter GWR & Keterangan \\
\hline Bandwidth & 20314,87 \\
Residual Squares & 42762,39 \\
Effective Number & 8,29 \\
Sigma & 30,59 \\
AICc & 533,32 \\
$R^{2}$ & 0,72 \\
$R^{2}$ Adjusted & 0,68
\end{tabular}

Sumber: Hasil olah data ArcGIS, 2020

Adapun nilai local $\mathrm{R}^{2}$ hasil analisis GWR tersaji dalam bentuk sebaran spasial per unit desa [Tabel 7 dan Gambar 8]. Nilai local $\mathrm{R}^{2}$ berkisar antara $0.44 \mathrm{~s} / \mathrm{d} 0.86$ dikategorikan menjadi 7 (tujuh) kelas. Kelas tertinggi bernilai $0.84 \mathrm{~s} / \mathrm{d} \quad 0.86$ diduduki desa-desa bagian selatan WP Tengah Kabupaten Bogor. Nilai $R^{2}$ tersebut diartikan juga bahwa fenomena alih fungsi lahan pada utara bagian WP Tengah Kabupaten Bogor yang terletak di sekitar suburban perkotaan dipengaruhi oleh faktor-faktor di luar administrasi pertanahan lebih besar daripada bagian selatan WP Tengah Kabupaten Bogor. Hubungan motif masyarakat dalam kegiatan administrasi pertanahan dengan konversi lahan menunjukkan lebih erat di bagian selatan WP Tengah. 
Tabel 7. Local $\mathrm{R}^{2}$ analisis GWR

\begin{tabular}{ll}
\hline Local R$^{2}$ & Desa \\
\hline $0.84-0.86$ & $\begin{array}{l}\text { Caringin, Ciadeg, Cibaruyut, Cinagara, Lemah Duhur, Pasir Buncir, Pasir Jaya, Pasir } \\
\text { Muncang, Tugu Jaya, Warung Menteng }\end{array}$ \\
$0.82-0.84$ & $\begin{array}{l}\text { Banjarsari, Banjarwangi, Cibalung, Cibedug, Ciderum, Cileungsi, Cimande, Cipelang, } \\
\text { Cipicung, Citapen, Pancawati, Tangkil, Telukpinang }\end{array}$ \\
$0.80-0.82$ & Cibanon, Palasari, Pandansari, Pasirangin \\
$0.70-0.80$ & Parakan, Pasireurih, Sukajaya, Sukaluyu, Sukamakmur, Sukaharja, Sukaresmi, Tajur \\
$0.56-0.70$ & Gunungsari, Pasirmukti \\
$0.50-0.56$ & Candali, Cibeuteung Udik, Karihkil, Pabuaran, Tegal \\
$0.44-0.50$ & Babakan, Bojong Sempur, Cibeuteng Muara, Ciseeng, Gunung Sindur, Iwul, Jampang, \\
& Kuripan, Parigimekar, Putat Nutug, Warujaya \\
\hline
\end{tabular}

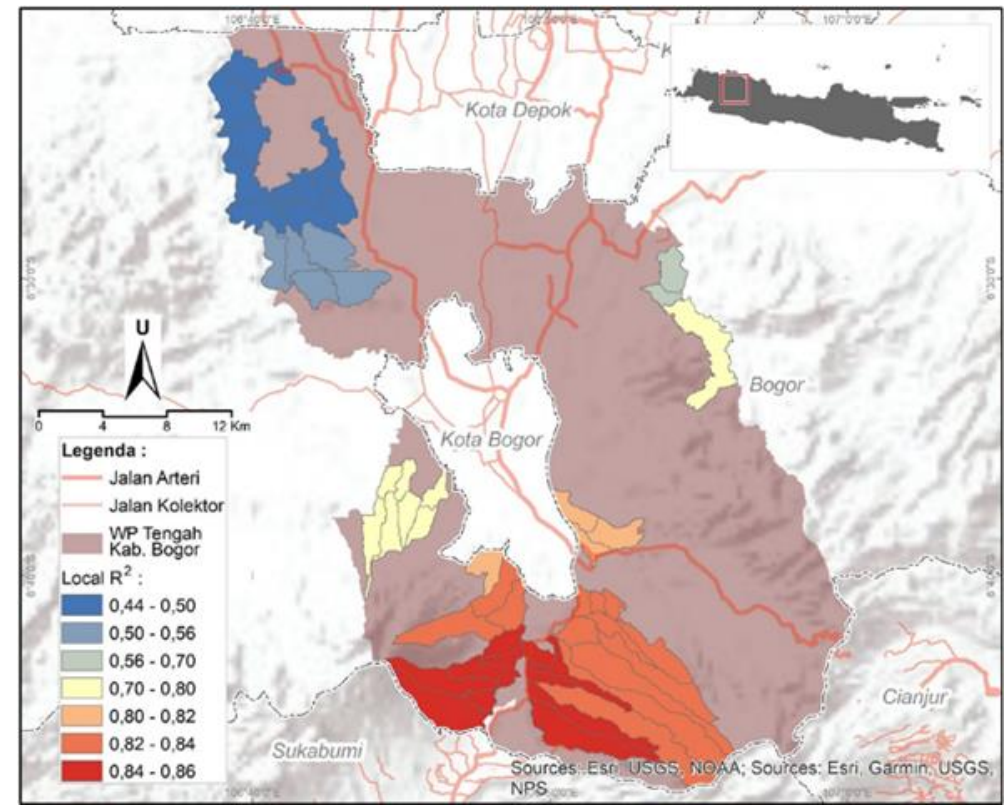

Gambar 8. Persebaran Local $\mathrm{R}^{2}$ hasil analisis GWR

Koefisien variabel $\mathrm{x}$ pemodelan GWR [Tabel 8 dan Gambar 9], terlihat bahwa koefisien pendaftaran tanah pertama kali dan pendaftaran hak tanggungan bernilai positif, sedangkan koefisien pemisahan bidang tanah dan peralihan hak bernilai negatif. Artinya bahwa ketika terjadi satu kegiatan pendaftaran tanah pertama kali atau pendaftaran hak tanggungan maka akan berdampak meningkatkan lahan terbangun di Kawasan Pertanian Lahan Basah sebesar nilai koefisien pendaftaran tanah pertama kali atau sebesar nilai koefisien pendaftaran hak tanggungan, dan sebaliknya untuk kegiatan pemisahan/pemecahan bidang tanah atau peralihan hak.

Tabel 8. Nilai Koefisien Variable $x$

\begin{tabular}{llll}
\hline Koefisien Variabel $\left(\boldsymbol{\beta}_{\boldsymbol{k}}\right)$ & Minimum & Maksimum & Rata-Rata \\
\hline Pendaftaran tanah pertama kali & 0.3603 & 0.8009 & 0.6963 \\
Pemisahan atau pemecahan bidang tanah & -0.8017 & -0.4267 & -0.7111 \\
Peralihan hak & -0.8973 & -0.2188 & -0.6961 \\
Pendaftaran hak tanggungan & 0.4650 & 1.2748 & 0.6155 \\
\hline
\end{tabular}



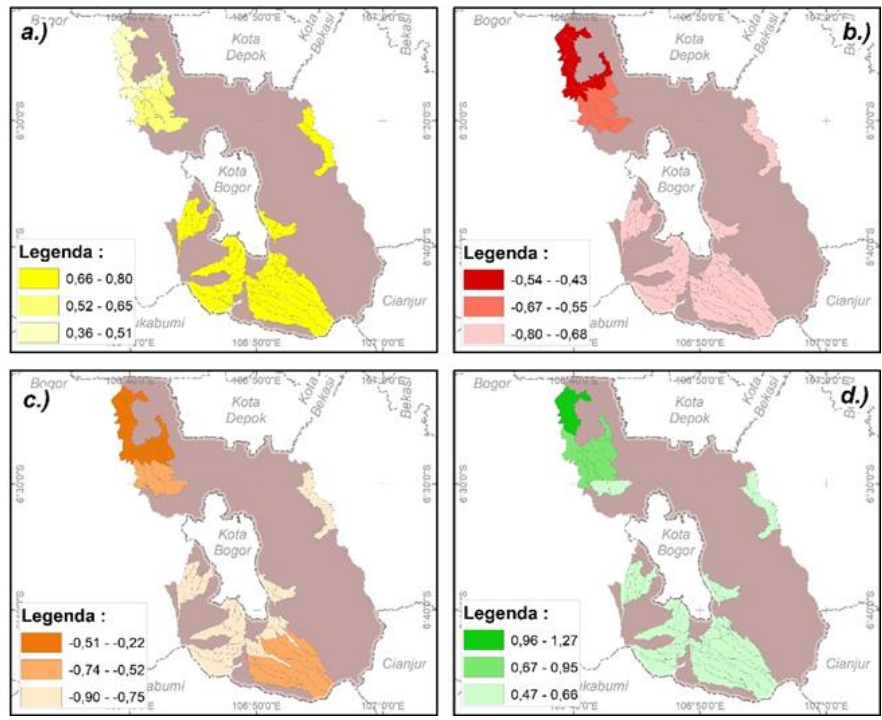

Gambar 9. Nilai koefisien: a.) Pendaftaran tanah pertama kali; b.) Pemisahan/pemecahan bidang tanah; c.) Peralihan hak; d.) Pendaftaran hak tanggungan

Koefisien variabel independen pendaftaran tanah pertama kali tersebar dengan pola semakin besar ke arah bagian selatan WP Tengah Kabupaten Bogor, selaras dengan persebaran nilai $\mathrm{R}^{2}$. Bagian selatan WP Tengah juga mempunyai rasio persil lahan terbangun dengan kecenderungan dominasi kelas tinggi (0.68 s/d 1) dan sedang (0.34 s/d 0.67). Padahal bagian selatan WP Tengah berciri lebih perdesaan daripada bagian utara WP Tengah dan tanah pada kawasan pertanian juga mempunyai nilai tanah atau land rent lebih rendah dari kawasan permukiman. Selain itu, masyarakat enggan melakukan pendaftaran tanah secara mandiri karena terkait dengan anggapan biaya yang mahal (Audina, 2018) dan (Cecilia, 2016). Tanah pertanian yang telah didaftarkan (bersertipikat tanah) tidak ada hubungannya dengan signifikansi produkstivitas pertanian (Belay, 2010). Sehingga, terlihat jelas motif masyarakat mensertipikatkan tanah pertaniannya karena akan dilanjutkan dengan perbuatan hukum dan atau teknis agraria yang akhirnya berdampak pada alih fungsi lahan (konversi lahan).

Hak tanggungan dan pemisahan/ pemecahan bidang memiliki koefisien variabel yang meninggi ke arah utara WP Tengah Kabupaten Bogor. Hal tersebut sejalan dengan fenomena kredit pemilikan tanah kavling siap bangun hasil pemisahan/pemecahan dengan agunan sertipikat tanah yang kian marak terjadi di wilayah suburban dari Kota Tangerang Selatan dan Kota Depok.

Meskipun koefisien pemisahan/ pemecahan dan koefisien peralihan hak bernilai negatif (-), namun cenderung meninggi ke arah bagian utara WP Tengah yang dapat diartikan bahwa dampak koefisien terhadap keberadaan lahan terbangun lebih tinggi di bagian utara daripada di bagian selatan WP Tengah. Bagian selatan WP Tengah dengan koefisien peralihan hak yang bernilai sedang $(-0.74 \mathrm{~s} / \mathrm{d}-0.52)$ dan rasio persil lahan terbangun dengan kecenderungan dominasi kelas tinggi $(0.68 \mathrm{~s} / \mathrm{d}$ 1) dan sedang (0.34 s/d 0.67) menandakan adanya fenomena alih fungsi lahan sawah secara tidak langsung yaitu diawali alih penguasaan atau pemilikan terlebih dahulu seperti yang telah diungkapkan oleh Sumaryanto et al. (2005).

Garda terdepan dari administrasi pertanahan adalah loket-loket Kantor Pertanahan dan Kantor Wilayah Badan Pertanahan Nasional, yang dalam pelaksaannya berpedoman pada Peraturan Kepala Badan Pertanahan Nasional RI No. 1 Tahun 2010 tentang Standar Pelayanan dan Pengaturan Pertanahan. Hasil studi Peraturan Kepala Badan Pertanahan Nasional RI Nomor 1 Tahun 2010 tentang Standar Pelayanan dan Pengaturan Pertanahan maka didapat penjelasan lebih lanjut 
tentang nilai positif (+) dan negatif (-) dari koefisien varibabel $\mathrm{x}$.

Persyaratan pelayanan berdasarkan pasal 6 Peraturan Kepala Badan Pertanahan Nasional RI Nomor 1 Tahun 2010 adalah persyaratan yang harus dipenuhi oleh pemohon yaitu masyarakat dan badan usaha, agar permohonannya dapat diproses kejenjang lebih lanjut. Persyaratan yang dimaksud meliputi dokumen pertanahan dan dokumen yang berkaitan dengan pertanahan. Permohonan yang tidak disertai dengan dokumen yang lengkap maka Kantor Pertanahan, Kantor Wilayah Badan Pertanahan Nasional menolak berkas permohonan.

Tabel 9. Standar Pelayanan dan Pengaturan Pertanahan

\begin{tabular}{|c|c|c|c|c|}
\hline Dokumen Syarat Permohonan & $\begin{array}{l}\text { Pendaftaran } \\
\text { Tanah Pertama } \\
\text { Kali }\end{array}$ & $\begin{array}{l}\text { Pemisahan } \\
\text { Bidang } \\
\text { Tanah }\end{array}$ & $\begin{array}{l}\text { Peralihan } \\
\text { Hak }\end{array}$ & $\begin{array}{l}\text { Hak } \\
\text { Tanggungan }\end{array}$ \\
\hline $\begin{array}{l}\text { Ijin Perubahan Penggunaan Tanah, apabila } \\
\text { terjadi perubahan penggunaan tanah }\end{array}$ & & $\sqrt{ }$ & & \\
\hline $\begin{array}{l}\text { Ijin Pemindahan Hak apabila di dalam } \\
\text { sertipikat/keputusannya dicantumkan tanda } \\
\text { yang menyatakan bahwa hak tersebut } \\
\text { hanya boleh dipindahtangankan jika telah } \\
\text { diperoleh ijin dari instansi yang berwenang }\end{array}$ & & & $\sqrt{ }$ & \\
\hline
\end{tabular}

Peraturan Kepala Badan Pertanahan Nasional RI Nomor 1 Tahun 2010 mensyaratkan adanya dokumen Ijin Perubahan Penggunaan Tanah dalam kegiatan pemisahan bidang tanah, apabila terjadi perubahan penggunaan tanah [Tabel 9]. Sedangkan, peralihan hak tanah pertanian mensyaratkan adanya dokumen Ijin Pemindahan Hak. Ijin tersebut tertulis/tercantum pada sertipikat/keputusannya yang menyatakan bahwa hak atas tanah tersebut hanya boleh dipindahtangankan jika telah memperoleh ijin dari instansi yang berwenang. Terkait pengendalian pemanfaatan ruang Kawasan Pertanian Lahan Basah WP Tengah Kabupaten Bogor maka dalam dokumen persyaratan terlihat bahwa kegiatan pemisahan bidang tanah dan peralihan hak memperhatikan unsur pengendalian alih fungsi lahan pertanian. Tanda negatif pada koefisien variabel tersebut dapat diartikan bahwa kegiatan pemisahan bidang tanah dan peralihan hak tidak menyebabkan dampak ikutan berupa penggunaan lahan terbangun dan bahkan menurunkan laju alih fungsi lahan pertanian menjadi lahan terbangun.

Dampak positif leburnya urusan penataan ruang pada Kementerian Pekerjaan Umum ke dalam kewenangan Kementerian Agraria dan
Tata Ruang Peraturan Presiden No. 17 Tahun 2015 yaitu memposisikan penyelenggaraan penataan ruang yang mencakup kegiatan perencanaan, pemanfaatan dan pengendalian pemanfaatan ruang kedalam bingkai land management (Deng, 2019). Artinya, administrasi pertanahan dapat berperan efektif dan efisien dalam pengendalian pemanfaatan ruang kawasan pertanian lahan basah jika unsur pengendalian alih fungsi lahan pertanian menjadi bagian dari dokumen persyaratan pelayanan. Sehingga, dalam strategi pengendalian pemanfaatan ruang maka persyaratan pelayanan dapat diperketat sebagai alternatif kebijakan pengendalian alih fungsi Kawasan Pertanian Lahan Basah.

Hubungan motif masyarakat dalam kegiatan administrasi pertanahan dengan konversi lahan menunjukkan lebih erat ke arah bagian selatan WP Tengah. Jadi, peran administrasi pertanahan dalam pengendalian alih fungsi lahan akan lebih efektif pada Kawasan Pertanian Lahan Basah di desa-desa bagian selatan daripada bagian uatara WP Tengah Kabupaten Bogor. 


\section{KESIMPULAN}

Dinamika administrasi pertanahan terbesar terjadi pada bagian utara WP Tengah Kabupaten Bogor pada desa-desa di wilayah suburban Kota Tangerang Selatan dan Kota Depok. Analisis GWR menghasilkan nilai global $\mathrm{R}^{2}$ sebesar 0.72 dan nilai local $\mathrm{R}^{2}$ sebesar $0.44 \mathrm{~s} / \mathrm{d} \quad 0.86$ yang artinya administrasi pertanahan berpeluang menjadi instrumen pengendalian alih fungsi lahan. Strategi pengendalian pemanfaatan ruang melalui administrasi pertanahan dengan cara memperketat persyaratan permohonan pelayanan di bidang pertanahan yang saat ini mengacu pada PerKaBan RI No. 1 Tahun 2010 tentang Standar Pelayanan dan Pengaturan Pertanahan.

\section{UCAPAN TERIMA KASIH}

Penulis mengucapkan terima kasih kepada Kementerian Agraria dan Tata Ruang/Badan Pertanahan Nasional, Kantor Pertanahan Kabupaten Bogor, yang telah memberikan kemudahan dalam mengakses data yang menunjang penelitian ini. Ucapan terima kasih juga penulis sampaikan kepada Beasiswa Pusbindiklatren Bappenas.

\section{DAFTAR PUSTAKA}

Amir, R. A., Barus, B., \& Soetarto, E. (2020). Dinamika Spasial Tanah Terdaftar dan Implikasinya terhadap Sistem Penghidupan Masyarakat Lokal di Kabupaten Takalar. Journal of Regional and Rural Development Planning (Jurnal Perencanaan Pembangunan Wilayah dan Perdesaan), 4 (2), 134-153.
Audina, B. (2018). Pelaksanaan Pendaftaran Hak Atas Tanah Pertama Kali Secara Sporadik Menurut Undang-Undang Pokok Agraria yang Tidak Dilakukan oleh Masyarakat di Desa Punggur Kecil Kecamatan Sungai Kakap Kabupaten Kubu Raya. E-Journal Fatwa Hukum Faculty of Law Universitas Tanjungpura, 1 (1).

Barus, B., Panuju, D., Iman, L., Trisasongko, B., Gandasasmita, K., \& Kusumo, R. (2011). Pemetaan Potensi Konversi Lahan Sawah dalam Kaitan Lahan Pertanian Berkelanjutan dengan Analisis Spasial. Dalam D.P. Ariyanto, WS Dewi, dan Suwardi (Penyunting). Pros. Semin. dan Kongr. HITI X, di Solo. Hal. 554-561

Belay, A. (2010). The effects of rural land certification in securing land rights: a case of Amhara region, Ethiopia. Unpublished Thesis Submitted to the International Institute for GeoInformation Science and Earth Observation, the Netherlands

[BPN RI] Badan Pertanahan Nasional RI. (2010). Peraturan Kepala Badan Pertanahan Nasional RI Nomor 1 Tahun 2010 tentang Standar Pelayanan dan Pengaturan Pertanahan. Jakarta: BPN RI

Cecilia, C. (2016). Meningkatnya Kesadaran Hukum Masyarakat dalam Melakukan Pendaftaran Tanah Warisan (Studi pada Kantor Pertanahan Kota Stabat). Premise Law Journal, 6, 1-23.

Deininger, K., Ali, D. A. \& Alemu, T. (2011). Impacts of land certification on tenure security, investment, and land market participation: Evidence from Ethiopia. Land Economics. https://doi.org/10.3368/le.87.2.312 
Endeng, E. (2019). Kewenangan Badan Pertanahan Nasional di bawah Kementerian Agraria dan Tata Ruang Badan Pertanahan Nasional Kabupaten Karawang. Jurnal Hukum Positum, 4 (1), 116.-134.

Djakapermana, R. D. (2009). Rencana Tata Ruang Kawasan Jabodetabekpunjur: Upaya Menyeimbangkan Pertumbuhan Ekonomi dengan Kelestarian Lingkungan Hidup. Buletin Online Tata Ruang, JuliAgust.

http://penataanruang.pu.go.id/bulletin/

Dwinanto, A. A. P., Munibah, K., \& Sudadi, U. (2016). Model Perubahan dan Arahan Penggunaan Lahan untuk Mendukung Ketersediaan Beras di Kabupaten Brebes dan Kabupaten Cilacap. TATALOKA, 18 (3), 157-171.

Fajarini, R., Barus, B., \& Panuju, D. R. (2015). Dinamika Perubahan Penggunaan Lahan dan Prediksinya untuk Tahun 2025 Serta Keterkaitannya Dengan Perencanaan Tata Ruang 2005-2025 di Kabupaten Bogor. Jurnal Ilmu Tanah dan Lingkungan, 17 (1), 8-15.

[Kementan] Kementerian Pertanian. (2019). Statistik Lahan Pertanian Tahun 20142018. Jakarta: Kementan

Mardiana, Y. S., Siregar, H., \& Juanda, B. (2016). Pengaruh Sertifikasi Tanah Terhadap Nilai Tanah Dan Kondisi Ekonomi Masyarakat Di Kabupaten Sukoharjo. Jurnal Aplikasi Bisnis Dan Manajemen (JABM), 2(3), 304.

Marzuki, A. (2018). Analisis Tingkat Perkembangan Wilayah, Konversi Tanah dan Rasio Tanah Terdaftar serta Arahan Pengembangan Wilayah di Kabupaten Cirebon. Institut Pertanian Bogor

Munawir, M., Barus, B., \& Sudadi, U. (2019). Analisis Spasial Dinamika Konversi Lahan Di Kabupaten Gowa, Sulawesi Selatan. TATALOKA, 21 (2), 237-252.
[Pemda Kab. Bogor] Pemerintah Daerah Kabupaten Bogor. (2016). Aspek Regional Kabupaten Bogor. [diakses 2020 Apr 16]. http://www.bogorkab.go.id [Pemda Kab. Bogor] Pemerintah Daerah Kabupaten Bogor. (2016). Peraturan Daerah Kabupaten Bogor Nomor 11 Tahun 2016 tentang RTRW Kabupaten Bogor Tahun 2016-2036. Cibinong: Pemda Kab. Bogor

Prabowo, H. L. (2019). Study of parcels-based Land Use Planning in Urban areas dan Rural Areas (Case Study of Mantrijeron Sub-district, Yogyakarta City and Bambanglipuro Sub-district, Bantul Regency). JGISE: Journal of Geospatial Information Science and Engineering, 2 (1), 171-184.

Pravitasari, A. E., Saizen, I., Tsutsumida, N., Rustiadi, E., \& Pribadi, D. O. (2015). Local Spatially Dependent Driving Forces of Urban Expansion in an Emerging Asian Megacity: The case of Greater Jakarta (Jabodetabek). Journal of Sustainable Development, 8 (1).

Sitorus, Mt. Felix, et al. Menuju Keadilan Agraria: 70 Tahun Gunawan Wiradi. Edited by Suhendar, Endang, et al, AKATIGA, 2002.

Sumarto, S., Nugroho, P., \& Prihandito, A. (2010). Penyediaan Tanah untuk Pemukiman di Kabupaten Kendal Studi Kasus Pengaplingan Tanah di Kelurahan Langenharjo. Forum Illmiah Tahunan, Ikatan Surveyor Indonesia, A-1-A-13

Sumaryanto, Friyatno, S., \& Irawan, B. (2005). Konversi Lahan Sawah ke Penggunaan Non Pertanian dan Dampak Negatifnya. Prosiding Seminar Nasional Multifungsi Lahan Sawah, 1-18.

Syahyuti, N. (2016). Delandreformisasi sebagai Gejala Anti Landreform di Indonesia: Karakter, Penyebab dan Upaya untuk Pengendaliannya. Forum Penelitian Agro Ekonomi, 29 (2). 